UDC 613.69: 684

DOI: $10.21668 /$ health.risk/2020.3.14.eng

Research article

\title{
COMPLEX APPROACH TO ASSESSING RISKS AND PREVENTING VARIOUS SOMATIC DISEASES IN WORKERS (EMPLOYED AT FURNITURE PRODUCTION)
}

\author{
N.A. Merkulova ${ }^{1}$, Yu.Yu. Eliseev ${ }^{2}$, O.I. Kozhanova ${ }^{1}$ \\ ${ }^{1}$ Federal Service for Surveillance over Consumer Rights Protection and Human Wellbeing, Saratov Region office, \\ 7 Vol'skaya Str., Saratov, 410028, Russian Federation \\ ${ }^{2}$ Saratov State Medical University named after V.I. Razumovsky, 112 Bol'shaya Kazach'ya Str., Saratov, 410012, \\ Russian Federation
}

At present a number of contemporary furniture production enterprises is growing fast in Saratov region. And simultaneously there is a growth in number of working places that require adequate sanitary-hygienic assessment of their safety.

Our research goal was to perform complex assessment of somatic diseases risks for workers employed at furniture production.

We examined 323 workers employed at «Maria» furniture factory. To perform assessment, we applied sanitary-hygienic, laboratory-instrumental, and statistic research techniques. It was established that $23 \%$ workers had to work under hazardous working conditions (hazard category 3.2); $37 \%$ workers had to work under conditions belonging to hazard category 3.1; $39 \%$ examined workers had optimal and acceptable conditions at their workplaces (category 1-2). Having examined workers' age groups, we revealed that workers aged 21-30 prevailed among the examined ones and average working experience amounted to 5.4 years for people of this age. The second in number were workers aged 31-40 with their working experience being equal to 8.5 years. At the next stage in our research we examined morbidity among workers employed at furniture production. Thus, it was established that diseases of the nervous system were the most frequent among the examined workers (33.3\%); they were followed by respiratory diseases (20.4\%), cardiovascular diseases (12.1\%), and digestive organs diseases (10.2\%).

The third stage involved examining hereditary burdens on morbidity among workers employed at furniture production. Thus, 108 workers were established to have various diseases and $79.6 \%$ of them had hereditary predisposition.

At the final stage in our research we examined retrospect data on changes in workers' life quality over 2015. The obtained data were compared with occurrence or absence of new diseases cases over the next three years.

Key words: furniture production, working experience, age, life quality, morbidity, hereditary predisposition, working conditions, workers.

Russia possesses huge amounts of timber occupying a leading place in the world as per this parameter. More than 2 million people work in forestry and wood-processing, 50\% out of them being employed at furniture productions. Over the last decades new workshops have been built and new production lines installed; it has led to qualitative changes in working conditions and processes at most workplaces in the branch. At present furniture productions are being equipped with more powerful and safer Russian and foreign machinery but still certain peculiarities of techno- logical processes applied in wood processing do not allow eliminating adverse impacts exerted on workers' health completely and they make efficient primary diseases prevention harder to achieve [1-3].

Given rapid industrial growth and economic development, issues related to occupational hygiene and preservation of employable population's health in the country are especially vital for wood processing industry. And not enough attention has been paid to dependence between health risk parameters and hazardous working conditions taking into account

(c) Merkulova N.A., Eliseev Yu.Yu., Kozhanova O.I., 2020

Nadezhda A. Merkulova - Chief Expert at the Department for the Surveillance over Communal Hygiene and Transport (e-mail: avtoladi@yandex.ru; tel.: +7 (905) 326-25-09; ORCID: https://orcid.org/0000-0002-8301-623X).

Yurii Yu. Eliseev - Doctor of Medical Sciences, Professor, Head of the Communal Hygiene and Ecology Department (e-mail: yeliseev55@mail.ru; tel.: +7 (919) 831-50-08; ORCID: https://orcid.org/0000-0002-6507-476X).

Ol'ga I. Kozhanova - Supervisor (e-mail: sarrpn@san.ru; tel.: +7 (8452) 220-18-58; ORCID: https:// orcid.org/0000-0001-7885-4469). 
not only leading adverse factors but also complex influence exerted by occupational factors and factors related to labor process existing at workplaces in furniture production. At the same time, models for assessing occupational health risks for workers in wood processing are applied only occasionally and described in very few scientific works ${ }^{1,2,3}[4-10]$.

Occupational peculiarities in wood processing are determined by production technologies, production equipment, automation and mechanization at a given enterprise; all this results in negative effects produced by adverse factors and predetermines their range and intensity. Issues related to preserving employable population's health remain extremely vital given contemporary economic development and it is also true for forestry and wood processing. Over the recent years there has been a growth in population mortality, in particular, among workers employed at such productions and it highlights the necessity to examine the issue in greater details [10]. A lot of authors mention a cause-and effect relation between high morbidity among workers employed in the branch and adverse occupational factors existing at their workplaces; this high morbidity includes cardiovascular diseases, diseases of the nervous system, respiratory and gastric diseases $^{4}[5,11-13]$. Up to now, hygienic standards have been basic tools applied to hygienically assess impacts exerted by adverse occupational factors on workers' health. Violation of these standards means simultaneous violation of sanitary legislation and it is taken into account when economic and social protection activities are developed. But the basic focus here is not on reducing potential risks but on compensatory measures. Given that, it is advisable to assess working conditions basing on complex analysis of occupational factors (hygienic and psychophysiological parameters) and detection of health disorders, occupational and work-related diseases as per medical criteria [13]. Occupational risk assessment is a promising technique applied to examine influence exerted by occupational factors on workers' health. But still, life quality (LQ) assessment is a promising additional technique that can be applied in the sphere since recently both Russian and foreign experts have been paying more and more attention to examining various aspects of dependence between health and life quality, both for population in general and specific population groups as well $[14,15]$. Life quality predetermines a person's health to a great extent. But health in its turn also influences life quality considerably. This thesis has been used in developing HRQL (Health-related quality of life) concept $[16,17]$.

At present many doctors and genetics adhere to an opinion that all the diseases are hereditary ones ${ }^{5}$ [18]. Such wide-spread chronic diseases as stomach and duodenum ulcer, hemophilia, pancreatic diabetes, ischemic heart disease, bronchial asthma, schizophrenia, hypercholesterolemia, and some others are diseases with poly-functional predisposition [18, 19]. However, we should note that such a factor as predisposition to a disease in this or that system has not been analyzed at all within assessing influence exerted by adverse factors on working population's health, in particular on health of workers employed at furniture production. It is important to note that most hygienic conditions are analyzed in retrospect, that is, the analysis assesses a disease that has already occurred. At the same time, to optimize organizational and prevention activities, one requires prospective examinations aimed at

\footnotetext{
${ }^{1}$ Trushkova E.A., Staseva E.V., Volkova N.Yu. Adverse occupational factors. Part I: Manual. Rostov-on-Don, Rostov State Building University Publ., 2014, 103 p. (in Russian).

${ }^{2}$ Safe life activities. Part 2. Occupational sanitary and hygiene: Manual. In: S.L. Pushenko, D.V. Deundyak, E.V. Omel'chenko, A.V. Nikhaeva, A.S. Pushenko, E.A. Trushkova, E.V. Staseva, E.V. Fedina, E.S. Fil' eds. Rostov-on-Don, Rostov State Building University Publ., 2014, 94 p. (in Russian).

${ }^{3}$ Polezhai M.N. Hygienic assessment of working conditions and occupational risks at contemporary furniture productions: thesis of the dissertation ... for Candidate of Medical Sciences. Saint Petersburg, 2010, 22 p. (in Russian).

${ }^{4}$ Retnev V.M. Occupational diseases and ways to prevent them: manual. Saint Petersburg, Dialekt Publ., 2007,240 p. (in Russian).

${ }^{5}$ Ginter E.K. Medical genetics. Moscow, 2003, 448 p. (in Russian).
} 
assessing risks occurring in specific working conditions when a medical and social status of a particular person is determined. However, very few works have focused on this issue in relation to furniture production [14].

Therefore, all the above mentioned issues existing within assessment of adverse working conditions at furniture production have not been given much attention; the same is true for predicting health risks existing in the brunch. Given that, the present work seems truly vital and of practical importance as it focuses on a specific example, namely, «Maria», a furniture mill located in Saratov region, one of the largest manufacturers in the country that produces furniture for kitchens.

Our research goal was to apply a complex approach to assessing risks of somatic diseases occurrence in workers employed at contemporary furniture production and to outline necessary stages in prevention.

Data and methods. Overall, we examined 323 workers employed at «Maria» furniture mill. We took only data on morbidity among men since women employed at the enterprises didn't have to work under hazardous working conditions. We also excluded workers who had already suffered from chronic diseases prior to being employed at the mill. We detected that at the moment the examination was taking place, $23 \%$ workers had to work under hazardous working conditions belonging to 3.2 hazard category; also, $37 \%$ had to work under working conditions belonging to 3.1 hazard category. But still, $39 \%$ workers had optimal and permissible working conditions at their workplaces (hazard category 1 and 2). People aged 21-30 prevailed among workers with average working experience being equal to 5.4 years for this age group. The second rank place belonged to workers aged $31-40$ with their average working experience being 8.5 years.
We applied sanitary-hygienic, laboratoryinstrumental and statistic research techniques in this work. Occupational factors were assessed as per Sanitary-Epidemiological Rules 2.2.4.3359-16 $6^{6}$. We determined noise and vibration at workplaces with «Assistent-S1V3RT» noise and vibration analyzer No. 102212. Working conditions were classified according to occupational hazards and threats, labor hardness and intensity as per Guide R.2.2.2006-057. Health-related life quality was assessed with Health Status Survey SF-36, a standard questionnaire. SF-36 contains 36 questions that are distributed into eight groups represented by 8 scales; they characterize physical functioning $(\mathrm{PF})$, role physical (RP), bodily pain (BP), general health $(\mathrm{GH})$, vitality (VT), social functioning (SF), role emotional (RE), and mental health $(\mathrm{MH})$. Research results were statistically processed with «Microsoft Excel 2010» and «STATISTICA-6.0» applied software packages. When performing statistical processing, we applied variations statistics techniques. Kolmogorov-Smirnov criteria assessment revealed that the examined sampling was normal; as a result, we applied parametric analysis technique given as $\mathrm{M} \pm \mathrm{m}$. Validity of discrepancies between groups was assessed with Student's t-test. Discrepancies were considered valid at $p<0.05$. To calculate relative and absolute risk, we applied results obtained via assessing risk factors (working experience, hereditary predisposition, a decrease in life quality during one year, and a worker's age) producing their effects on 131 workers employed at furniture production; 17 workers didn't face any risk factors; 18 workers had to face one risk factor; 26 workers, two; 47 workers, three, and 40 workers, all four factors. Absolute and relative health risks were assessed according to conventional techniques in all the above mentioned groups.

${ }^{6}$ SER 2.2.4.3359-16. Sanitary-epidemiologic requirements to physical factors at workplaces. Approved by the RF Chief Sanitary Inspector on June 21, 2016 No. 81. KODEKS: an electronic fund for legal and reference documentation. Available at: http://docs.cntd.ru/document/420362948 (19.04.2020) (in Russian).

${ }^{7}$ Guide R 2.2.2006-05. Occupational hygiene. Guide on hygienic assessment of occupational factors and factors related to labor process. Working conditions criteria and classification. Approved by the RF Chief Sanitary Inspector G.G. Onishchenko on July 29, 2005. KODEKS: an electronic fund for legal and reference documentation. Available at: http://docs.cntd.ru/document/1200040973 (19.04.2020) (in Russian). 
Results and discussion. We analyzed occurrence of various diseases among workers employed at contemporary furniture production and possible relations between them and working conditions using results obtained via profound medical examinations performed in 2018. Overall, 323 workers employed at «Maria» were examined.

Figure 1 illustrates the structure of detected diseases. Diseases of the nervous system prevailed among workers employed at furniture production $(33.3 \%)$; they were followed by respiratory diseases $(20.4 \%)$, diseases of the cardiovascular system $(12.1 \%)$, and gastric diseases $(10.2 \%)$. There were no sufficient data on other nosologies for statistical processing; therefore, the further analysis was performed as per functional systems only.

Figures 2 and 3 show the structure of the diseases diagnosed for the first time taking into account working experience and working conditions as per nosologies.

Having analyzed morbidity with diseases of the cardiovascular system (CVS), we established that there were no new disease cases among workers with their working experience being equal to 2-3 years and with working conditions belonging to category 3.1 at their workplaces. However, four new disease cases were registered among workers with their working experience exceeding three years. Morbidity among workers who had to work under working conditions belonging to hazard category 3.2 grew by 3 times from 2-year experience to 3 -year one; it doubled further for workers with their working experience exceeding three years as a number of new cases amounted to six.

Morbidity with respiratory diseases grew by 5 times among workers with their working experience exceeding 5 years and working under hazardous conditions (hazard category 3.1). Morbidity among workers who had to work under conditions belonging to 3.2 hazard category already grew when working experience was from two to three years as there were seven new disease cases; when working experience under these conditions exceeded 3 years, morbidity grew further by $42.8 \%$ and reached 10 new disease cases.

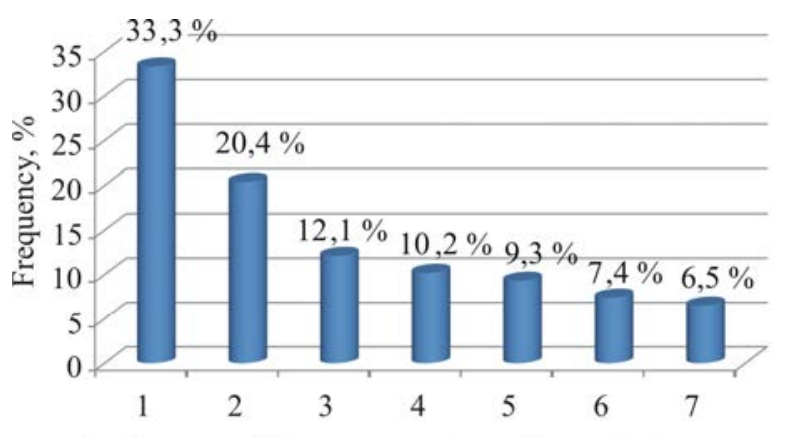

1 - diseases of the nervous system; 2 - respiratory diseases; 3 - diseases of the CVS; 4 - gastric diseases; 5 -diseases of the musculoskeletal system; 6 -diseases of the endocrine system; 7 -idseases of the eye and its accessory apparatus

Figure 1. Frequency of various diseases among workers employed at furniture production

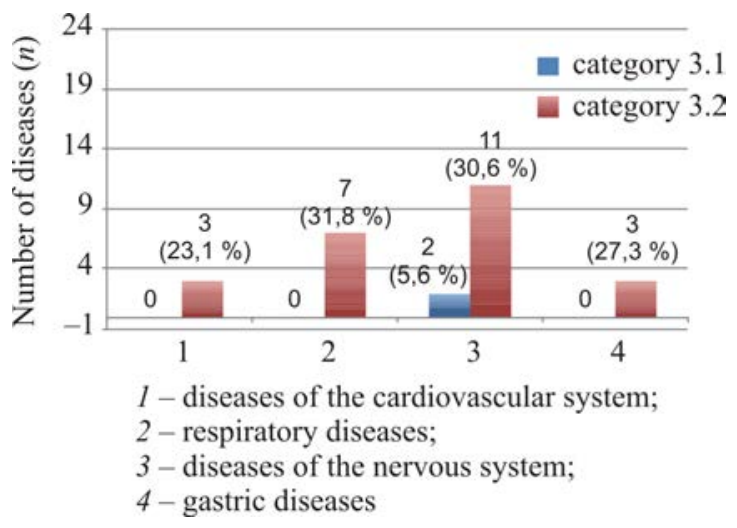

Figure 2. Structure of diseases diagnosed for the first time with working experience being equal to 2-3 years distributed as per working conditions category

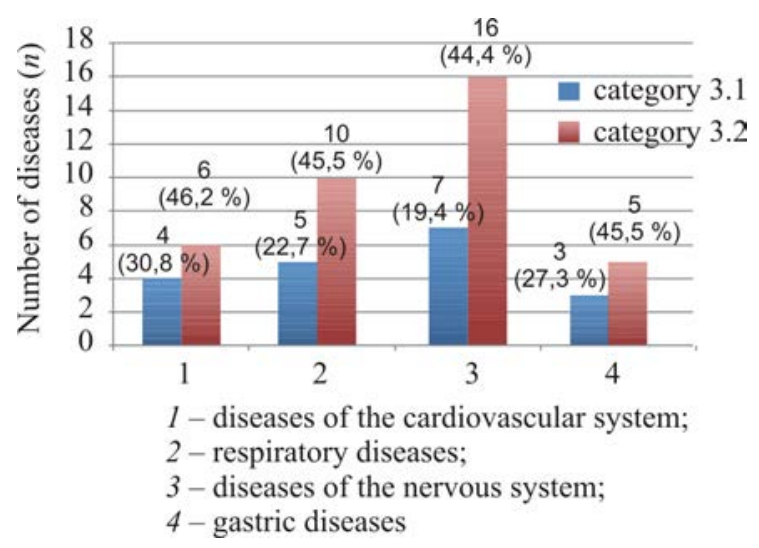

Figure 3. Structure of diseases diagnosed for the first time with working experience being longer than 3 years distributed as per working conditions category

Morbidity with diseases of the nervous system also tended to grow. Two new disease cases were detected among workers who had to work under hazardous conditions belonging 
to 3.1 hazard category and with their working experience being from 2 to 3 years. Morbidity grew by 2.5 times (seven new cases) among workers with their working experience exceeding 3 years. 11 new disease cases were registered among workers with their working experience being from 2 to 3 years who had to work under conditions belonging to hazard category 3.2. Morbidity grew further by $45.5 \%$ and reached 16 cases among workers with their working experience exceeding 3 years.

As for gastric diseases, 3 new disease cases were detected among workers with their working experience exceeding 3 years and working conditions at their workplaces belonging to hazard category 3.1. Morbidity grew by 3 times among workers who had to work under conditions belonging to hazard category 3.2 and with their working experience being from 2 to 3 years. Morbidity grew by $66.7 \%$ among workers having the same conditions at their workplaces but with working experience exceeding 3 years and reached 5 new cases of gastric diseases.

If we sum up all the data, given on Figures 2 and 3, we can conclude that risks of various diseases for workers employed at furniture production grow in proportion to their working experience and labor hardness. The most adverse effects are produced by these factors on the nervous system.

108 workers out of 323 examined ones employed at «Maria» furniture mill had various diseases; $79.6 \%$ of them were caused, among other things, by hereditary predisposition. We examined influence exerted by hereditary predisposition on frequency of diseases occurrence in workers employed at furniture production and working under adverse working conditions belonging to hazard categories 3.1 and 3.2 and their working experience exceeding 3 years (Figure 4).

Having analyzed the obtained data, we came to a conclusion that hereditary predisposition was an unfavorable factor causing various diseases in workers employed at furniture production in case labor hardness and intensity were comparable (hazard category 3.1 and 3.2) and working experience was the same (longer than 3 years). In particular, diseases of the

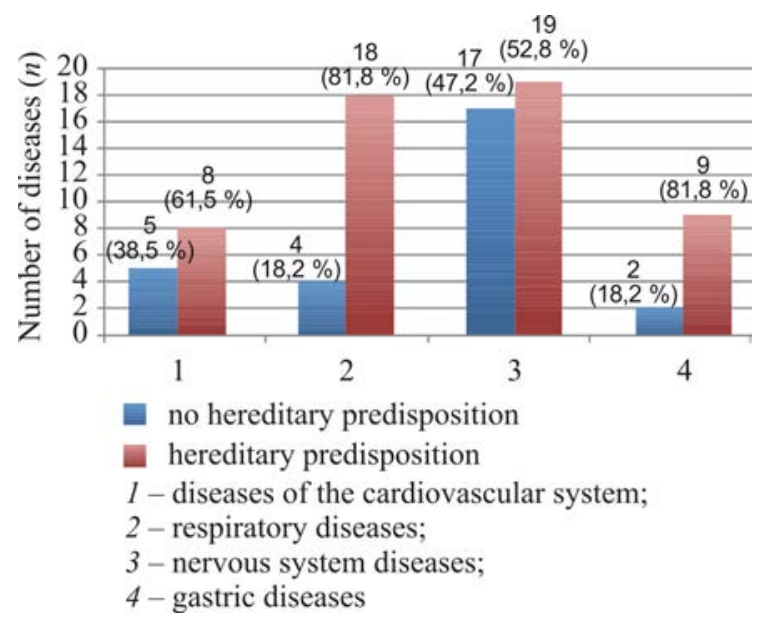

Figure 4. Morbidity among workers taking into account absence/occurrence of hereditary predisposition and given hazardous working conditions (3.1 or 3.2 hazard category) and working experience exceeding 3 years

cardiovascular system occurred only in 5 workers without hereditary predisposition after working experience exceeded 3 years; when it was present, 8 new cases were registered. Overall, we can conclude that workers employed at furniture production with hereditary predisposition and working experience longer than 3 years run a risk of cardiovascular diseases that is by $60.0 \%$ higher than that for their counterparts without hereditary predisposition.

The same situation was detected when it came down to respiratory diseases. 18 new disease cases were registered among workers with hereditary predisposition to such diseases and it was by $77.8 \%$ higher than among workers who had no hereditary predisposition to them. If we look at morbidity with diseases of the nervous system, we can see than 17 new disease cases were registered among workers who didn't have any hereditary predisposition to such diseases. However, in case hereditary predisposition was present, a number of hew cases amounted to 19 and it was by $11.8 \%$ higher than among workers without it. 2 new gastric diseases cases were registered in workers without hereditary predisposition and with working experience exceeding 3 years. But frequency of gastric diseases was by 3.5 times higher among workers with hereditary predisposition.

To sum up our analysis of influence exerted by hereditary predisposition on this or 
that disease among workers employed at furniture production, we should note that growth in morbidity is more apparent among workers with hereditary predisposition with working conditions and experience being comparable.

The final stage in our research involved examining retrospect data on changes in life quality of workers employed at the examined furniture mill that occurred in 2015; the obtained data were then compared with absence or occurrence of new disease cases during the following 3 years.

Analysis of data given in Table 1 indicates that a decrease in life quality of workers employed at furniture production that is equal to $30 \%$ and higher during 1 year is an unfavorable factor that predicts various diseases occurrence in the next 3 years. In particular, people who were diagnosed a cardiovascular disease in the examined period had a $29.4 \%$ decrease in their life quality in a year prior to the examined period; $32.1 \%$ decrease in case a disease of the nervous system occurred; $31.8 \%$ for a respiratory disease; and a $33.5 \%$ decrease for a gastric diseases. At the same time, workers who didn't have any new disease registered during the examined period had less significant decrease in their life quality, by $15.1 \%, 13.3 \%, 10.6 \%$ and $13.3 \%$ accordingly $(p \leq 0.05)$. Taking all the obtained data into account, we can conclude that a different decrease in workers' life quality during 1 year indicates that greater decrease in life quality results in greater growth in risks of various pathologies occurrence during the next 3 years ( $30 \%$ and higher).

We determined absolute and relative risks of various somatic diseases taking into account all the above-mentioned parameters (Table 2).

The $1^{\text {st }}$ group didn't have any risk factors; it was made up of 17 workers employed at furniture production with only one new disease case among them. The following groups given

Table 1

Changes in life quality parameters of workers in 2015 depending on absence or occurrence of a disease during the next 3 years, taken in dynamics in scores

\begin{tabular}{|c|c|c|c|c|c|c|}
\hline \multirow{3}{*}{ Nosology } & \multicolumn{6}{|c|}{$\begin{array}{c}\text { LQ parameters as per SF-36 scales, } \\
\text { Sn (integral index) }\end{array}$} \\
\hline & \multicolumn{3}{|c|}{$\begin{array}{l}\text { No disease } \\
n=126\end{array}$} & \multicolumn{3}{|c|}{$\begin{array}{c}\text { A disease occurred } \\
n=82\end{array}$} \\
\hline & Initial data & 1 year after & Changes, \% & Initial data & 1 year after & Changes, \% \\
\hline Cardiovascular system & $68.3 \pm 8.6$ & $59.3 \pm 6.8$ & $-15.1 \%$ & $68.3 \pm 8.6$ & $48.2 \pm 4.3 *$ & $-29.4 \%$ \\
\hline Respiratory organs & $67.2 \pm 7.8$ & $60.1 \pm 7.1$ & $-10.6 \%$ & $67.2 \pm 7.8$ & $45.8 \pm 5.2 *$ & $-31.8 \%$ \\
\hline Nervous system & $70.1 \pm 6.9$ & $60.8 \pm 5.8$ & $-13.3 \%$ & $70.1 \pm 6.9$ & $47.6 \pm 6.1 *$ & $-32.1 \%$ \\
\hline Gastrointestinal tract & $69.3 \pm 6.3$ & $60.1 \pm 4.8$ & $-13.3 \%$ & $69.3 \pm 6.3$ & $46.1 \pm 5.1 *$ & $-33.5 \%$ \\
\hline
\end{tabular}

$\mathrm{N}$ o t e : $*$ means $p<0.05$ against the pervious group.

Table 2

Contingence of risk factors for a disease occurrence and their realization during the next 3 years

\begin{tabular}{|c|c|c|c|c|c|c|c|c|}
\hline \multirow{2}{*}{$\begin{array}{c}\begin{array}{c}\text { Analyzed } \\
\text { groups }\end{array} \\
\end{array}$} & \multicolumn{2}{|c|}{ Observation results } & \multirow{3}{*}{$\begin{array}{l}\text { Absolute } \\
\text { risk in the } \\
\text { test group }\end{array}$} & \multirow{3}{*}{$\begin{array}{l}\text { Absolute } \\
\text { risk in the } \\
\text { control } \\
\text { group }\end{array}$} & \multirow[b]{3}{*}{$\begin{array}{l}\text { Relative } \\
\text { risk } \\
\text { (RR) }\end{array}$} & \multirow[b]{3}{*}{$\begin{array}{l}\text { Discre- } \\
\text { pancy }\end{array}$} & \multirow[b]{3}{*}{$\begin{array}{c}\text { Sensitivity } \\
\text { (Se) }\end{array}$} & \multirow[b]{3}{*}{$\begin{array}{l}\text { Specificity } \\
(\mathrm{Sp})\end{array}$} \\
\hline & Outcome & No outcome & & & & & & \\
\hline $\begin{array}{l}\text { A number } \\
\text { of risk factors }\end{array}$ & 1 & 16 & & & & & & \\
\hline 1 & 2 & 16 & 0.11 & 0.05 & 1.88 & 0.05 & 0.66 & 0.5 \\
\hline 2 & 8 & 18 & 0.32 & 0.05 & 5.23 & 0.24 & 0.88 & 0.47 \\
\hline 3 & 21 & 26 & 0.47 & 0.05 & 7.5 & 0.38 & 0.95 & 0.38 \\
\hline 4 & 24 & 16 & 0.62 & 0.053 & 11.4 & 0.54 & 0.96 & 0.52 \\
\hline
\end{tabular}


in Table 2 had risk factors, from one to all four. The group with only one risk factor consisted of 18 workers and 2 out of them actually fell sick during 3 years of working and 16 workers employed at the examined furniture mill didn't have any disease diagnosed in them during this period. Therefore, absolute probability of a disease occurrence in this group amounted to 0.11 ; relative probability was 1.88 . Similarly, results obtained for groups with two, three or four risk factors are given in Table 2. In particular, in case there were two risk factors, two workers employed at furniture production had a disease diagnosed in them and other 18 in the same group didn't. Therefore, absolute risk of diseases occurrence in this group amounted to 0.32 , and relative probability was equal to 5.23. The next group consisted of 47 workers who had three risk factors; 21 out of them had a diseases while the rest 26 didn't; therefore, absolute probability of a diseases occurrence amounted to 0.47 in this group whereas relative risk grew up to 7.5. The group with four risk factors consisted of 40 workers and 24 out of them had a disease while the rest 16 didn't. Absolute risk amounted to 0.62 in this group; relative one, 11.4. Therefore, as we can see from this table, a probability of a disease occurrence grows substantially if a number of risk factors increases.

\section{Conclusions:}

1. Morbidity among workers employed at furniture production depends on working conditions and working experience. Morbidity is 1.4 times higher among workers older than 40 than among those aged from 21 to 30 .

2. Morbidity growth is 3.9 times more apparent among workers with hereditary predisposition than among those without it even if their working conditions are the same.

3. Various somatic pathologies developing in workers employed at furniture production are to a great extent caused by impacts exerted by such adverse factors as hazardous working conditions, hereditary predisposition, age, working experience, and a decrease in life quality by more than $30 \%$ during 1 year.

4. A decrease in workers' life quality during 1 year by $30 \%$ or more indicates there is high risk of various diseases occurrence in the next three years.

5. Our research allows assessing risks of various somatic diseases taking into account working experience, hereditary predisposition, decrease in life quality, and age of a specific worker.

Funding. The research was not granted any sponsor support.

Conflict of interests. The authors declare there is no any conflict of interests.

\section{References}

1. Polezhai M.N. Gigienicheskaya kharakteristika uslovii truda rabochikh v derevoobrabatyvayushchem proizvodstve [Hygienic characteristics of working conditions for workers employed at wood processing production]. Sovremennye podkhody $k$ prodvizheniyu zdorov'ya: materialy II Mezhdunarodnoi nauchno-prakticheskoi konferentsii. Gomel', 2008, pp. 87-89 (in Russian).

2. Polezhai M.N., Sharko B.N., Rad'kova E.A. Gigienicheskaya otsenka uslovii truda na osnovnykh etapakh pererabotki drevesiny [Hygienic assessment of working conditions existing at basic stages in wood processing]. Meditsina truda. Zdorov'e rabotayushchego naseleniya: dostizheniya i perspektivy: materialy XXXIX Vserossiiskoi nauchnoi konferentsii s mezhdunarodnym uchastiem (Khlopinskie chteniya). Sankt-Peterburg, MAPO Publ., 2009, pp. 204-206 (in Russian).

3. Polezhai M.N., Chernova G.I., Vorob'eva L.V. Gigienicheskie podkhody k otsenke zdorov'ya naseleniya $\mathrm{v}$ raione razmeshcheniya predpriyatii po pererabotke drevesiny [Hygienic approaches to assessing population health on a territory close to wood processing enterprises]. Akademik AMN SSSR Zakharii Grigor'evich Frenkel'. 140 let so dnya rozhdeniya: materialy memorial'noi nauchnoi konferentsii. Sankt-Peterburg, 2009, pp. 338-340 (in Russian).

4. Trushkova E.A., Oleinikov P.D. Izuchenie sovremennykh metodov diagnostiki professional'nykh zabolevanii [Examining contemporary techniques for occupational diseases diagnostics]. Molodoi uchenyi, 2016, vol. 122, no. 18.1, pp. 27-28 (in Russian).

5. Smailova L.F. Gigienicheskaya otsenka uslovii truda na predpriyatiyakh tsellyuloznobumazhnoi promyshlennosti [Hygienic assessment of working conditions at pulp and paper productions]. Materialy 
mezhinstitutskoi nauchnoi konferentsii, posvyashchennoi 60-letiyu obrazovaniya MGSMU kafedry obshchei gigieny. Moscow, 2006, pp. 18 (in Russian).

6. Kosarev V.V., Babanov S.A. Health preservation for working population: problems and optimization methods. Meditsina truda i promyshlennaya ekologiya, 2011, no. 1, pp. 3-7 (in Russian).

7. Trushkova E.A., Volkova N.Yu. Results of studying the problem of the acoustic safety of equipment AT «Krasnokamsky remontno-mekhanichesky zavod» JS. Nauchnoe obozrenie, 2014, no. 11, pp. 528-531 (in Russian).

8. Trushkova E.A., Volkova N.Yu. Development of activities aimed at preventing injuries and professional diseases AT «Rostvertol» JSC. Nauchnoe obozrenie, 2014, no. 10, pp. 550-553 (in Russian).

9. Hanson N., Guttman E., Zarsson A. The effect of different holding conditions for environmental monitoring with coge rainbow trouth (Oncorhynchus mykiss). J. Environ Monit, 2006, vol. 8, no. 10, pp. 994-999. DOI: 10.1039/b608862g

10. Sokolova L.A., Dracheva A.A. Health of workers of sawing and woodaprocessing industry. Ekologiya cheloveka, 2005, no. 6, pp. 44-47 (in Russian).

11. Bulatova S.I., Kunevskaya E.V. Organizatsiya Gossanepidnadzora na predpriyatiyakh derevoobrabatyvayushchei otrasli [Organization of the State Epidemiologic Surveillance at wood processing enterprises]. Materialy X S"ezda gigienistov i sanitarnykh vrachei. Moscow, 2007, pp. 1024-1027 (in Russian).

12. Mikkelsen A.B., Schliinssen V., Sigsgaard T., Schaumburg I. Determinants of Wood Dust Exposure in the Danish Furniture Industry. Ann. Hyg, 2002, vol. 46, no. 8, pp. 673-685. DOI: 10.1093/annhyg/mef082

13. Samigova N.R., Mirsagatova M.R., Barakaev F.I. Izuchenie dinamiki izmenenii v funktsional'nom sostoyanii serdechno-sosudistoi sistemy rabochikh mebel'nogo proizvodstva [Examining dynamics of changes in functional state of the cardiovascular system of workers employed at furniture production]. Molodoi uchenyi, 2017, vol. 184, no. 50, pp. 126-129 (in Russian).

14. Cherepanov D., Palta M., Fryback D.G. Underlying dimensions of the five health-related quality-of-life measures used in utility assessment: Evidence from the National Health Measurement Study. Medical Care, 2010, vol. 48, no. 8, pp. 718-725. DOI: 10.1097/MLR.0b013e3181e35871

15. Horsman J., Furlong W., Feeny D., Torrance G. The Health Utilities Index (HUI): Concepts, measurement properties and applications. Health and Quality of Life Outcomes, 2003, vol. 16, no. 1, pp. 54. DOI: $10.1186 / 1477-7525-1-54$

16. Baumann C., Erpelding M.L., Perret-Guillaume C., Gautier A., Regat S., Collin J.F., Briancon S. Health-related quality of life in French adolescents and adults: Norms for the DUKE Health Profile. BMC Public Health, 2011, vol. 11, pp. 401. DOI: 10.1186/1471-2458-11-401

17. Hawthorne G. Assessing utility where short measures are required: Development of the short Assessment of Quality of Life-8 (AQoL-8) instrument. Value Health, 2009, vol. 12, no. 6, pp. 948-957.

18. Torosyan A.A. Rasprostranennost' nasledstvenno predraspolozhennykh zabolevanii sredi naseleniya goroda Stepanakerta [Prevalence of hereditary diseases among people living in Stepanakert]. Innovatsionnoe razvitie, 2016, vol. 1, no. 1, pp. 26-27 (in Russian).

19. Govbakh I.A. Populyatsionno-epidemiologicheskie aspekty nasledstvennykh boleznei nervnoi sistemy [Population and epidemiologic aspects of hereditary nervous system diseases]. Science Rise, 2015, vol. 7, no. 4, pp. 54-60 (in Russian).

Merkulova N.A., Eliseev Yu.Yu., Kozhanova O.I. Complex approach to assessing risks and preventing various somatic diseases in workers (employed at furniture production). Health Risk Analysis, 2020, no. 3, pp. 116-123. DOI: 10.21668/health.risk/2020.3.14.eng

Received: 05.06.2020

Accepted: 18.08 .2020

Published: 30.09.2020 